\title{
Public Intervention and Open Market System in Health Services
}

\author{
M. Hanifi Aslan, Filiz Gölpek² \\ ${ }^{1,2}$ Faculty of Economic and Administrative Sciences, Hasan Kalyoncu University, \\ Gaziantep/Turkey
}

\begin{abstract}
In many economies, a significant proportion of service production is organized within market system. In the market system, the units in this organization base their economic activities on profit and benefit maximization. However, in most parts of service sector, pure competition conditions may not be valid. Health services are different from the goods which are produced and distributed by the open market. While some activities which are within the scope of health services are close to the definition of "public", most of them have the characteristics of semipublic goods and services. Considering the importance which the mentioned services have regarding the society with their social benefits and the social costs which they will cause unless they are produced sufficiently, it could be argued that besides the open market, the public should also produce these services. The aim of this study is to present the insufficiency of market system in producing health services and analyze the intervention methods of public in order to compensate the insufficiency.
\end{abstract}

Keywords: Health, health economy, health services, market failure, social intervention.

\section{Council for Innovative Research}

Peer Review Research Publishing System

\section{Journal: International Journal of Management \& Information Technology}

Vol. 9, No. 2

editor@cirworld.com

www.cirworld.com, member.cirworld.com

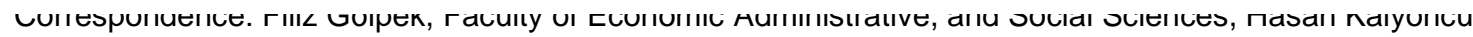
University, School of Business and Social Sciences, Gaziantep, Turkey. Tel: 0342 211 80 80-1337, E-mail: filiz.golpek@hku.edu.tr 


\section{INTRODUCTION}

In many economies, a significant proportion of service production is organized within market system. This organization includes private persons, households, companies and other institutions. Economic activities, in a market system, are based on profit and benefit patterns. In this system, sources are allocated through price mechanism among various services as in goods. Companies, which cannot determine the price of a service single-handedly under pure competition conditions, pursue profit and allocate their sources to optimum fields. However, perfect competition market conditions may not be valid in most parts of the service sector. For instance, full information and homogeneity conditions may not occur. A clear information asymmetry between suppliers and consumers may be the case in many services mainly in health and education. Classical monopolists may emerge in the case of leaving these services to private sector.

The subjects to be researched include the questions whether or not the health care services are different from the services which are produced and distributed by the market and why public intervention is needed in order to reach the goals of the public in terms of health care services.

Main purpose of this study is to analyze the failure of market system in providing health care services and the role of public sector in compensating it within a theoretical framework. Analyses focus on mainly individual health care services. This is considered particularly in terms of providing diagnostic and treatment services, open market system and state intervention. Within this framework, the study consists of four parts including introduction and conclusion. In the second part, open market system in health care services is approached under the subheadings of advantages and shortcomings of the system. Inadequacy of market system in health care services which includes five sections is analyzed under the following subheadings: uncertainty of demand, information asymmetry, monopolist tendencies, externalities and purpose of justice in the third part, state intervention in health care services is discussed under the subheadings of state intervention, that is state itself provides service, regulating health care services market and subsidies. In the conclusion part, it is suggested that public intervention along with the open market system in health care services is required.

\section{OPEN MARKET SYSTEM IN HEALTH CARE SERVICES}

Open market system in health care services is not a common practice in certain Western European countries, particularly in England. For instance, the state in England has provided all individuals with free or highly subsidized health care service since the end of World War II. On the other hand, in the U.S.A, the large part of these services is provided within open market system. In addition, private health insurance is a widespread practice in the U.S.A. A healthy population did not accompany economic growth in post war period in which significant amount of resources were allocated to health care services in the U.S.A. Mortality rate was high among Afro-american children and infectious diseases were widespread (Mortan and Tokgöz, 1984:1; OECD, 2012).

On the other hand, insistence on providing free or highly subsidized health care service has made it impossible to handle budget load in England, where health care services are provided almost wholly by public sector within the framework of national health care service. These two examples indicate that the problem is related to not only lack of resources but also efficiency. A serious state intervention is needed in the systems which are extremely based on market system while market motives are needed in the systems in which extreme state intervention is in question (Mortan and Tokgöz, 1984: 2; Stiglizt, 1994: 352).

\subsection{Advantages Of Open Market System}

The machinery of open market systems in health care services can be defined as the following: (1) Hospitals, as profit-oriented institutions, implement the prices which they determine according to kind and period of service. (2) Doctors, independently from health institutions, may provide examination and treatment services in their private clinics. (3) Medications and other medical stuff which are produced by private companies are sold to hospitals, doctors and patients (Aslan, 1998: 204).

Motives of free choice and efficiency may be argued in order to defend such a health care system. Free choice is one of the advantages of open market system and indicates the patients' freedom of choice. This encourages hospitals and physicians to be more sensitive to choices and needs of patients. Efficiency, another advantage of open market system, takes place when hospitals and physicians who demand high prices start losing customer and when a customer flow shift from of poor quality hospitals and physicians to the higher quality ones is the case. Thus, in the long term, companies and physicians who work on high costs will have to leave the market. These factors improve the quality in health care sector and reduce the cost. These factors improve quality in health care sector and reduce the costs. A health care system based on market mechanism which takes preferences of individuals into consideration works on minimum cost and efficiently (Fuchs, 1978: 190-92).

\subsection{Shortcomings Of Open Market System}

Health care services can be provided by the market due to their characteristics. These services can be marketed due to individual demand and, as a rule, can be produced in the market and offered to consumers. However, importance of these services for the society, their social benefit and social costs which will occur in the event that they are not supplied sufficiently lead in state's supply as well as market (Nadaroğlu, 2000: 33). 
Consequently, the notion that health care services cannot be marketed as other goods and services are underlies the shortcomings of market system.

The characteristics of market system which hinder health care services to be supplied and delivered efficiently can be gathered under five subheadings: (1) Demand uncertainty, (2) Information asymmetry between supplier and require, (3) Monopolist tendencies, (4) Externalities and (5) Purpose of justice (Tatlıoğlu, 1992: 27).

Demand uncertainty: an important characteristic of health care services is that they are unpredictable because it is uncertain when a disease will occur and individuals will apply to a hospital. Thus, it is very difficult for individuals to save money for unexpected health spending. If the share of treatment costs in household budget were small, it would not pose a problem. In many cases, health spending may be substantial amount (Aslan, 1998: 279).

As a solution to this uncertainty in demand, health insurance may be utilized. In general, objective of health insurance is to reduce the risks which individuals have to take and heading these risks towards the higher income groups. Many countries have an insurance program which aims to assist to afford health expenses. Although health insurance plays an important role in reducing the risks which are taken by individuals, it also has important effects. Some of these effects are positive while others are negative. Positive effect is that health expenses can be made smoothly when needed. Individuals start demanding unnecessary health care services which they would not in the event that they do not have health insurance (Fuchs, 1986: 16).

Such negative sides as misuse, adverse selection and ethical risks are in question in providing health insurance. For instance, in the event that health insurance system affords the whole treatment costs, both physicians and patients may exaggerate in terms of treatment: period of treatment and diagnostic tests more than required or patients' unnecessary application to physician may result in extravagance. Similar behaviors may occur even in the event of partial cover of the treatment fee. Such behaviors lead health care services to be purchased even when marginal benefit of these services is less than marginal social cost. Health insurance system encourages it. Here, demand will be determined by private cost, in other words, the share which policy holder must afford. If this share is very small amount of total treatment cost, for instance $20 \%$, health care service will be demanded as little as the amounts which provide little marginal benefit (Aslan, 1998: 207).

In addition to such behaviors of the suppliers and requirers of health care services, it is also named ethical risk that the policy holder acts in a way to cause the subject matter of insurance to materialize or to pave the way for it. Such behaviors may emerge in many cases where the price is paid by third parties. A policy holder's acts which put his health at risk may be an example. Governments intervene with it by regulating special insurance coverage, financing social insurance or providing health care service (Katouzian, 1970: 362).

Information asymmetry: a significant information asymmetry exists between the supplier of health care services such as physicians and health institution, and the consumer. Consumers have the opportunity of trying various goods. This helps them when they are in need of repurchasing the goods. However, this is not the case in health care services. Patients are clueless about the adequacy and efficiency of treatment. Furthermore, many treatments are irretrievable. When a treatment is found out to be inappropriate, it may be too late for another treatment (Tordoir, 2007: 82).

Consumers cannot obtain information which will allow them to make a rational choice pre, during and post treatment period. On the other hand, physicians and health institutions have full information on diagnosis and treatment. An exact information asymmetry exists between vendors and purchasers in health care services (Aslan, 1998: 214). In this case, validity of the argument that market system will encourage physicians and hospitals to provide better service is open to question. If the consumers do not know the difference between good and bad treatment, it is not possible for them to choose the physicians or hospitals which provide higher quality service. This is one of the important reasons for market system to be ineffective in health care services.

Monopolist tendencies: various industries in service sector differ greatly from manufacturing sector and each other by market structure, company size, ownership and management. Certain aspects of perfect competition conditions may not exist in most of the service industries. For example, entrance to and exit from the market, grounding and homogeneity conditions may not exist. In the event of leaving some certain services in which economy of scale becomes prominent, monopolists companies may emerge. Organization forms which range from monopolist competition to monopoly but are clear of perfect competition may be the case (Riddle, 2007: 92).

Information asymmetry between suppliers and consumers in health care service market causes those who provide health care services to monopolize. It reduces the competition among physicians and health institutions that consumers have difficulty in making a selection. Suppliers may act like monopolies by increasing prices and impairing the quality without customer loss concern. This indicates that efficiency incentives which exist in a rather competitive market do not present in health care services (Stiglizt, 1994: 361).

Externalities: while analyzing profit and benefit maximization of suppliers and consumers, market system does not consider the effects named externalities. Sometimes, acts of economic units, either they are suppliers or consumers, affect not only themselves but only others. It does not turn the balance that these acts are related to either production or consumption. Externalities are pertinent to these. In other words, if production or consumption behaviors of economic units affect cost and benefit functions of other economic units, it can be argued that these activities external effects (Dinler, 1993:173-76). 
Providing health care services through market system may result in certain problems due to the fact that they have external benefits as well as private benefits. Externality comes into prominence when certain health services and infectious diseases are on the carpet (Aktan and Tosuner, 1986: 144). To illustrate, those who are vaccinated against various diseases serve for reducing the risk of infecting others with the same. In the same way, a hospital which cures an infectious disease provides external benefit thanks to the fact that it prevents others to come into contact with the disease. Because, externalities are present in health care services, social benefit of a health care service is equal to the total amount of private and external benefits (Aslan, 1998: 215; Aktan, Dileyici and Vural, 2011: 21).

In the event of both positive and negative externalities, the state intervenes with service production when necessary. In the event of positive externalities, it tries to make up the deficient production by either participating in production or promoting private sector with various instruments. Intervention to health care services can be considered within this framework. In the event of negative externalities, it discourages such activities through intervention or provides certain services in order to compensate adverse effects (Aksoy, 1991: 63; Gölpek, 2013: 145).

If externality is a considerable extent, market system will lose its efficiency. In the event of paid cholera vaccination, individuals will only focus on private benefits and costs which they bear. Not considering external benefit will lead to deficient demand of these services. The said demand is presented with $Q_{0}$ in Figure 1 . Drawing demand curve by adding external benefit to private benefit, demanded amount will be $Q_{1}$ and vaccination service will be consumed in optimum quantity. If external benefit is not considered, demanded amount will be $Q_{0}$. This amount is not socially optimal. Presence of externality and not reflecting it on demand curve will prevent the market to operate efficiently (Aslan, 1998: 210).

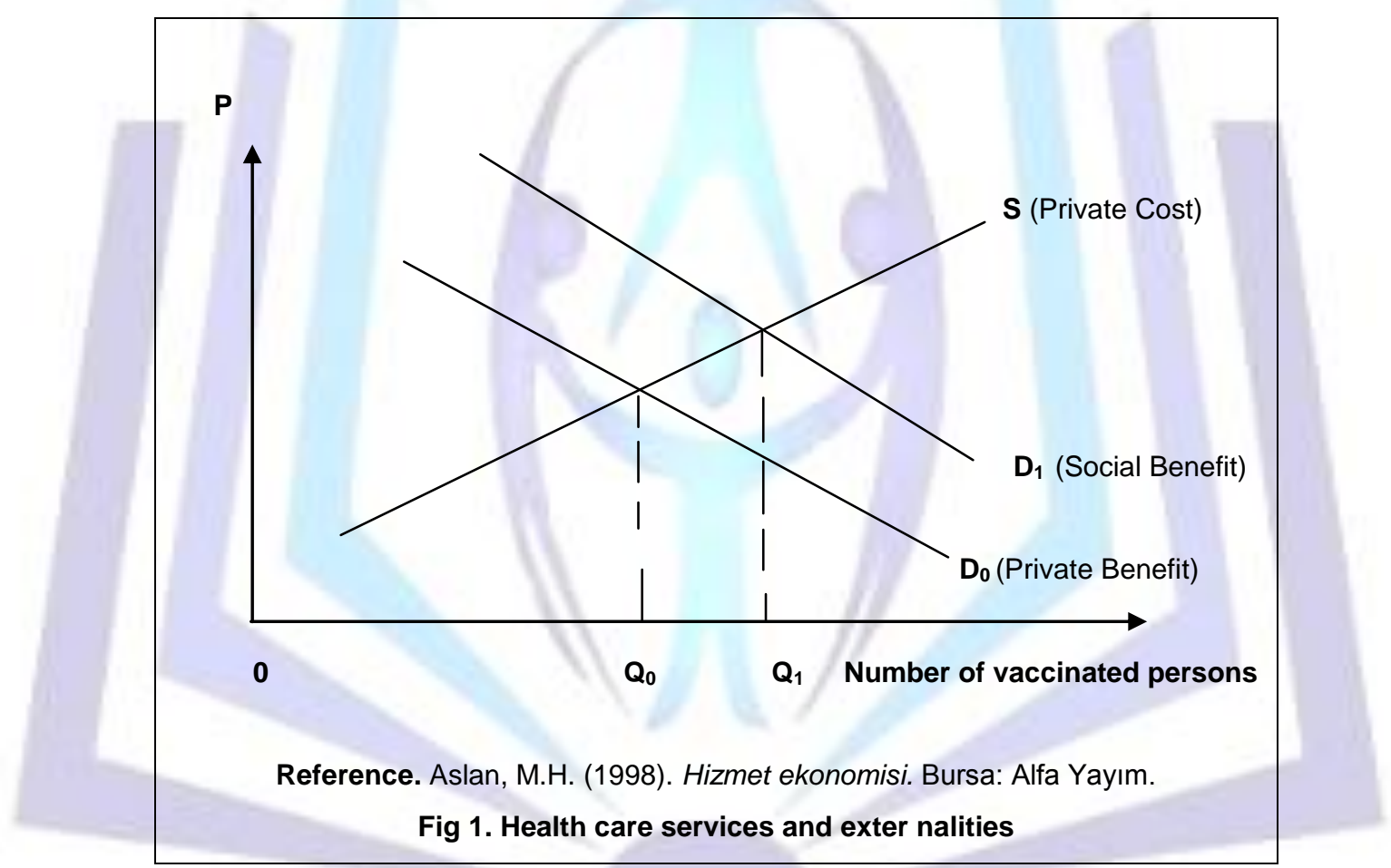

Here, it can be argued that external benefits of health care services are relatively small in practice, and thus, efficiency loss resulted from this is also small. This assertion has two bases. (1) Today, infectious diseases are not widespread. (2) Treating these is the only health care service which provides external benefit (Cropper, 2007: 1273).

However, both arguments can be objected. Certain infectious diseases such as AIDS and Hepatitis B are still common. If the health care services were based on only market system, they would be even more common. Furthermore, treating infectious diseases is not the only health care service which provides external benefits. Such externalities are likely to be related to various treatment types.

Justice issue: it is a common belief that health care services cannot be delivered justly through market system. Justice in health care services includes the following alternatives; (1) Providing a minimum standard health care service regardless of income level, (2) Grounding medical protection on income level and (3) Providing everybody with health care services as much as needed regardless of income level (Gadrey, 2007: 125).

When applying market mechanism, these principles may have a tendency to fail. In private health services market, the poor will not be able to receive the health care service of which they are in need; consequently, they will not be able to reach a minimum standard service. The high income groups will be able to purchase better treatment, and thus, unequal treatments for the same need will come into question. Competition conditions confront individuals with the same financial cost and price for health care services and the mentioned price means more self-sacrifice for the poor. 
This is because treatment fees correspond to a significant proportion of income of the low income group. Therefore, equality in accessing health care services in market system will be irrelevant. Basic differences between competitive markets and health care service market underlie all these market failures. This difference is in such an extent that it means health care service market is alienated from the characteristics of perfect competition market (Stiglitz, 1994: 360).

If the conditions of perfect competition market were valid for health care service market, the physicians and hospitals who provide better diagnosis and treatment services with lower prices would attract customers from others. Consequently, innovation and cost reduction would be encouraged. However, this is not the case. Because of deficient competition conditions, individuals wait standing at the hospitals and prices do not reduce due to ineffective physicians and hospitals. These characteristics of health care markets determine the intervention style of the state.

\section{PUBLIC INTERVENTION IN HEALTH CARE SERVICES}

State intervenes with the economy in different ways and at various levels. Public saving and investment are one part of fiscal policy of state. Fiscal policy is pertinent to the decision structure of public sector regarding spending, taxation and borrowing. Role of state goes beyond fiscal policy and extends over adjustment policies. State manages private economic operation, establishes regulations and implements them. Among them are trading rules regarding private contracts, companies regulations on establishment of new companies, regulation against trusts and on protection of the environment (Sachs and Felipe, 1993: 188).

The characteristics of market system which hinder efficiency and social optimization to be maintained in providing health care services have necessitated different ways of providing health care services, particularly state intervention forms, to be taken into consideration (Öztürk, 2011: 16). However, the market system failure in reaching economic and social goals in health care services does not automatically mean that state intervention is more efficient. State policies on this issue may be far from being satisfactory.

State intervention in health care services occurs in three forms. State; (1) itself offers service, (2) Regulates health care services market, or (3) Taxes the market (Tatlığlu, 1992: 27-34).

Undoubtedly, intervention forms are mainly based on the delivery method of health care services in a country. To illustrate, in England, state contributes health-care costs significantly. State has the biggest employer position for health care personnel. It trains physicians and other health care personnel, inspects them and sets standards for it. It renders health care services free or highly subsidized. Taxation/subsidy instruments and regulations, as intervention methods, become prominent in the U.S.A. where market system is more dominant in health care services (Coppierters, 2007: 89-98).

These intervention methods can be considered as response to the problems which open market system causes or the characteristics of health care service market. While information deficient of consumers is compensated through the regulations which state makes, monopolist tendencies are prevented through state's entrance to health care services as a supplier. Justice concerns, externalities and demand uncertainty are subdued through subsidy practices.

\subsection{State's Regulation Of Health Care Services}

State's regulation of health care services is related to the fact that consumers are deprived of knowledge through which they evaluate the treatment. State itself evaluates and guarantees the quality of health care services. A regulation on this includes various aspects from the personnel who will provide the service to organization and method of providing the services (Sachs and Felipe, 1993: 189).

State requires such licenses as diploma and certificate of compliance from those who provide the health care services. It designates the education content and principles of medicine, nursing, laborant etc. It makes regulations pertaining to the companies which provide health care services. It sets standards for hospitals.

However, an important concern is on the carpet. While making regulations, people who are in practice are set to work. Physicians come into play in designating the period and curriculum of medical and other medicine-related professions. Examinations are conducted by the physicians. Physicians take part in curriculum committees and participate in performance assessment of other physicians. This implies that regulations may be made not in favor of consumers but those who are subject to them. For instance, physicians may intend to limit the physician and service supply by extending education period and making it difficult to start the actual performance of the profession after graduation. However, educational standards which are valid all over the world are compensator factors of the negative possibility that regulations are made in favor of those who provide health care services (Tatlıoğlu, 1992: 35-38; Aslan, 1998: 211-13).

\subsection{Health Care Service Delivery By State}

The aforesaid information asymmetry between suppliers and consumers contributes the monopolist tendency of health care service providers. The state itself may provide health care services in order to break the monopolist tendencies which emerge as explained. It may become a monopsony in purchase of health care services. Thus, prices can be reduces through the agreements which are made with monopolist units. Cheap medicine and medical stuff can be obtained. Low wages can be applied to health care personnel. To illustrate, the state in England buys the medicine at half price compared to other countries and pays physicians a salary less than the amount which 
physicians in the U.S.A. and other Western Countries receive. Thus, state may procure cheaper facilities, equipment, machinery and tools used in health care services by using its monopsony or big buyer position (Cropper, 2007: 127477).

However, all health care services delivery by state may also pose some problems. In such an event, the state itself may pose an obstacle to competition. Absence of competition annihilates incentives related to efficiency. Moreover, state may not allocate enough resources to health care services. Cumbersome bureaucracy may hinder services to be delivered at the required pace.

The examples of the problems which may occur in delivery of the services by the state itself may be given from England and Turkey. In England, physicians are paid in terms of the number of patients who are treated. Thus, physicians want to examine large number of patients in a short period and quality reduces. System encourages working with small number of physicians. Few examinations and treatments can be provided in a certain period of time in such a system (Cropper, 2007: 1278). On the other hand, in Turkey, salaries of the physicians at SSI (Social Security Institution) hospitals are not in terms of the amount of services which they provide. In the present case, the patients who are contacted in private clinics can be cared by using the facilities of the hospitals. Because any relation between the income which physicians earn and the number of the patients who are examined or treated does not exist, it is encouraged to work with a large number of physicians. This results in increase of average personnel cost per patient in the state hospitals.

\subsection{Public Subsidies In Health Care Services}

Existence of externalities in health care services is the main reason for these services to be subsidized by the public. Health care services are produced below socially optimum level in the market system due to the externalities. It increases the demand that state provides subsidy and reduces the price, amount of service reaches optimal level (Şener, 2010: 57).

Degree of subsidy ranges from free treatment to slight reduction of the prices. However, it can be argued that the price does not need to be reduced to zero in order to maintain efficiency. It is enough to reduce the prices to the extent that individuals are convinced to demand required amount of service. Reduction of the price to zero may lead to extreme increase in demand and becoming more than desired. It will increase the cost burden on the society that subsidies lead to health care service demand more than required. If increase in demand is not recompensed with increase in supply, long queues arise and arbitrary allocation of services comes into question (Aslan, 1998: 215). This is presented in Figure 2.

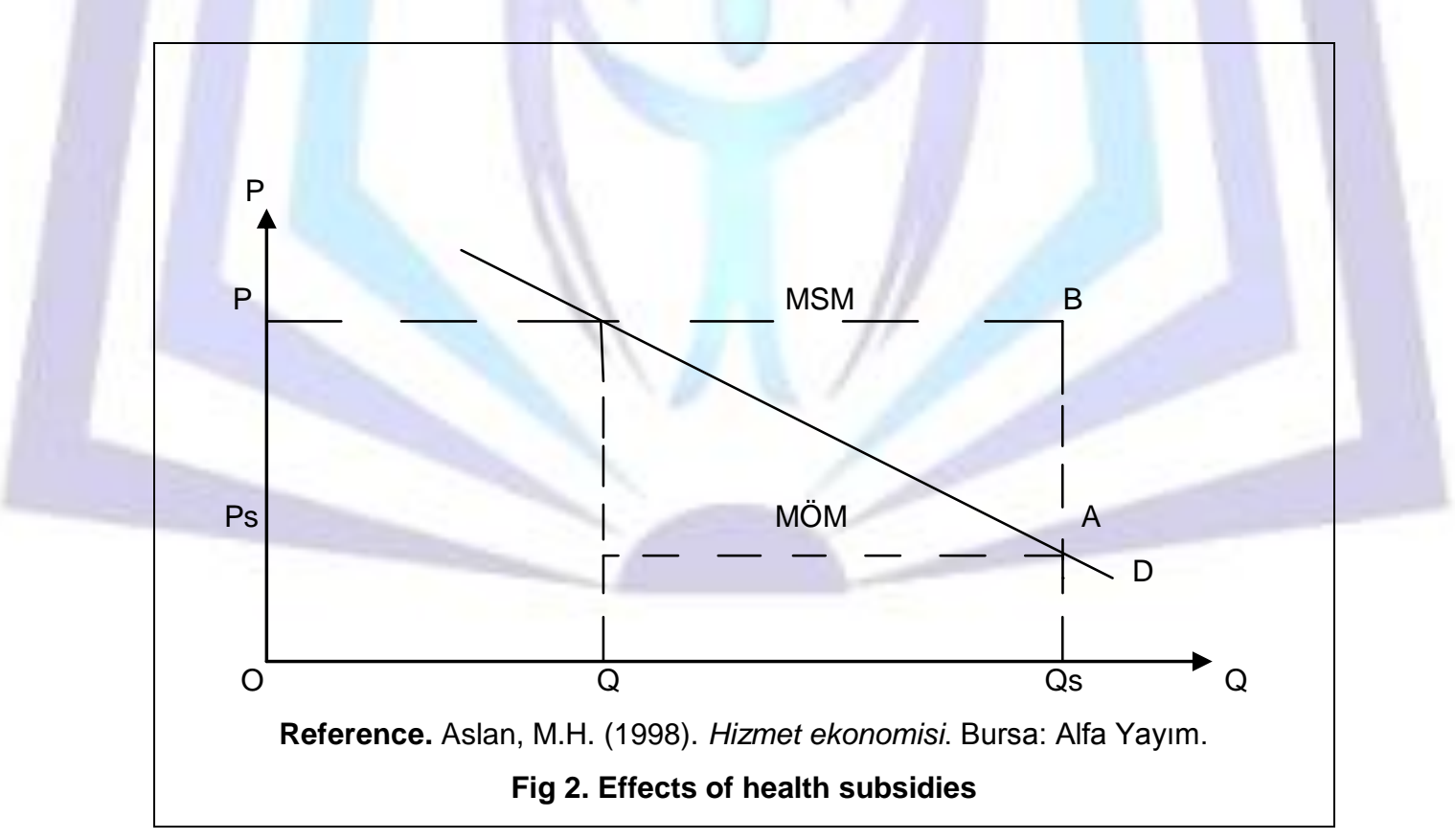

The price and amount of health care services fall into vertical and horizontal axis in Figure 2, respectively. $P$ is the price without subsidy and, at the same time, equal to marginal private cost (MPC). If subsidy were not provided, amount of demanded service would be equal to $Q$ and whole cost would be paid by the one who would benefit the service. This may not be socially optimum amount. However, in the case of subsidy, the amount of demanded health service will increase to $Q_{s}$. This may be more than optimal due to the fact that the price is quite low. It can be observed that as the amount of demanded health service increases, its marginal benefit decreases. Marginal benefit equal to $Q_{s}$ is equal to $A Q_{s}$. However, its incremental cost on the society is $A B$. Quite a little benefit (AQs) is obtained from a service for which a socially costly amount $\left(B Q_{S}\right)$ is paid. Thus, subsidies need to be at a level or rate which does not lead to redundant consumption. 
Here, the main purpose is to unfurl the fact that another justification for the state to subsidize health care services is based on the principle of justice as well as the goal of reaching optimum consumption level. However, it depends on the form of subsidy and justice definition whether or not this purpose is served through subsidies. Subsidies may applied to either those who receive income below a certain level as in the U.S.A. or all persons in the same form as in England (Akehurst, 2007: 11). In other words, these services are provided everybody for free or with a highly subsidized price. While common subsidies correspond to the justice definition which is providing everybody with health care services in minimum standard, income level based subsidy is in rapport with the justice definition which underlines costs not to hinder receiving health care services. Income based subsidy inflicts less cost upon the low income individuals while the high income individuals bear more costs. Thus, it is equalized to reach health care services (Coppierters, 2007: 99).

\section{CONCLUSION}

Governments, even in the most liberal countries, finance or supply health care service. Public finance of these services are based on economic efficiency, justice and market failures.

Health care services can be provided by the market due to their characteristics, marketed due to individual demand and, as a rule, can be produced in the market and offered to consumers. However, importance of these services for the society, their social benefit and social costs which will occur in the event that they are not supplied sufficiently lead in state's supply as well as market

In a health care system, it is crucial to allocate sizeable amounts in order to provide the best possible standard service. Increase in health spendings leads to budgetary deficit. Governments are in search of alternatives to public finance which are maintained through tax revenues. The share which is allocated to health spendings competes with the other usage areas of tax revenues in the budgets of governments and, in private sector, other consumption expenditures and individual savings.

For private sector, free choice and efficiency may be argued in order to defend such a health care system. Free choice encourages hospitals and physicians to be more sensitive to choices and needs of patients. Efficiency compels the institutions and physicians who work with high costs to leave the market in the long term due to free choice.

Social costs which are created by the open market require the public besides the open market to supply the services. However, uncertainty of demand, information asymmetry between the requirer and supplier, monopolist tendencies, externalities and the justice principle causes market failure. It results in monopolist tendencies that it is generally uncertain when people will apply the hospital or a physician, patients are clueless about the adequacy and efficiency of the treatment. However, those are the main justifications of state intervention that both suppliers and consumers do not take externalities into consideration in the event of profit and benefit maximization, and the poor cannot purchase the required treatment in minimum standard.

State intervention in health care services occurs in that state itself offers service, it regulates health care services market, or taxes the market. These intervention methods can be considered as response to the problems which open market system causes or the characteristics of health care service market. While information deficiency of consumers is compensated through the regulations which are made by the state, monopolist tendencies are prevented through the fact that state penetrates the market as a health care service supplier. Justice concerns, externalities and uncertainty of demand are subdued through subsidies. Public intervention besides open market system exists in health care services.

\section{REFERENCES}

[1] Akehurst, G. (2007). Economic of services: An introduction. London: Frank Cass.

[2] Aksoy, Ş. (1991). The economics of services: An introduction. London: Frank Cass.

[3] Aktan, C. \& Tosuner, M. (1986). Dışsal ekonomiler. Dokuz Eylül Üniversitesi Iktisadi ve Idari Bilimler Fakültesi Dergisi, 1(1), 142-156.

[4] Aktan, Ç.C., Dileyici, D. \& Vural, İ.Y. (2006). Kamu ekonomisi ve kamu politikası. (2. Basım). Ankara: Seçkin Yayıncılık.

[5] Aslan, M.H. (1998). Hizmet ekonomisi. Bursa: Alfa Basım Yayım.

[6] Bulutoğlu, K. (2008). Kamu ekonomisine giriş: Demokraside devletin ekonomik bir kuramı (7. Basım). Ankara: Maliye ve Hukuk Yayınları.

[7] Coppierters, P. (2007). Development of the services sector: A critical survey of macro-economic models. London: Frank Cass.

[8] Cropper, F. (1990). Economists and defence: The views of a UK practitioner. Defence Economics, 1(1), 75-84.

[9] Cropper, M.L. (). Healty, investment in health and occupational. Journal of Political Economy, 85(6), 1273-1285.

[10] Dinler, Z. (2011). Mikroekonomi (17. Basım). Bursa: Ekin Kitabevi. 
[11] Fuchs, V. (1986). The service economy. New York: National Burea of Economic Research.

[12] Gadrey, J. (2007). The double dynamics of services. London: Frank Cass.

[13] Gölpek, F. (2013). Health economics. International Journal of Business and Social Science, 4(17), (Special Issue-December), 144-152.

[14] Katouzian, M.A. (1970). The development of the services sector: A new approach. Oxford Economic Papers, 22(3), 362-82.

[15] Mortan. K. \& Tokgöz, T. (1984). Sağlık ekonomisi ve eğitimi. Ankara.

[16] Nadaroğlu, H. (2000). Kamu maliyesi teorisi. (11. Basım). İstanbul: Beta Basım Yayım.

[17] OECD (2012). Health at a glance. Retrieved June 05, 2013, from http://www.oecd.org.

[18] Öztürk, N. (2011). Kamu ekonomisi. Bursa: Ekin Basım Yayıncılık.

[19] Riddle, D. (). The role of service sector in economic development: Similarities and differences by development category. New York: Pergamon Books. 83-104.

[20] Sachs, D. \& Felipe, B. (1993). Macroeconomics in the global economy. New York: Harvester Wheatsheaf.

[21] Şener, O. (2010). Kamu ekonomisi. (11. Basım). İstanbul: Beta Basım Yayım.

[22] Stiglizt, J. (1994). Kamu ekonomisi. (2. Basım). (Çev: Ö.F. Batırel). İstanbul: Marmara Üniversitesi İ.İ.B.F Yayın No:396.

[23] Tatıığlu, İ. (1992). Sağlık hizmetlerinde finansman sorunu. Uludağ Üniversitesi, Sosyal Bilimler Enstitüsü. Yayınlanmamış doçentlik çalışması. Bursa.

[24] Tordoir, P. (2007). Services markets and the economics of social interaction. London: Frank Cass. 